\title{
A new, simple technique for gradual primary closure of fasciotomy wounds
}

\author{
Mustafa Özyurtlu, M.D., ${ }^{1}$ Süleyman Altınkaya, M.D., ${ }^{2}$ \\ Yahya Baltu, M.D., ${ }^{2}$ Güzin Yeşim Özgenel, M.D. ${ }^{2}$ \\ ${ }^{1}$ Department of Plastic Surgery, Bursa Sevket Yilmaz Training and Research Hospital, Bursa \\ ${ }^{2}$ Department of Plastic, Reconstructive and Aesthetic Surgery, Uludag University Faculty of Medicine, Bursa
}

\begin{abstract}
BACKGROUND: The aim of this study was to demonstrate a new, easy and safe technique, which has not been defined in the literature previously, that enables the gradual primary closure of fasciotomy wounds using barbed sutures.

METHODS: The technique was performed on five patients who presented with fasciotomy wounds on both upper and lower extremities, varying in size, observed after compartment syndrome due to different causes. The average width of the defects for which primary closure was planned was $8.8 \mathrm{~cm}$. Following the fasciotomy incision, absorbable barbed sutures were inserted through the dermal tissue around the wound similar to that of a subcuticular closure, but left loose, after which closed dressing was applied. During the clinical follow-up, with the decrease in tissue edema and tightness around the wound, the barbed suture was tightened at bedside every 48-72 hours.

RESULTS: At the end of this gradual closure, all the fasciotomy defects were primarily closed within an average of 8.6 days. All the patients had complete and uncomplicated primary closure with the exception of one with high-voltage electrical burn injury, who developed necrosis in the distal part of the defect, and was treated by secondary healing.
\end{abstract}

CONCLUSION: The gradual fasciotomy closure technique with barbed suture seems to be an easy, rapid and effective method.

Key words: Barbed sutures; compartment syndrome; fasciotomy wounds; gradual primary closure.

\section{INTRODUCTION}

Various reconstructive strategies may be performed for the closure of fasciotomy wounds that are secondary to compartment syndrome. Of these, closure via skin grafts and delayed gradual primary closure are the most commonly employed methods. In the early period, fasciotomy wounds can be closed easily with partial or full-thickness skin grafts. With this method, the risk of wound infection is avoided; however, the long-term outcome may carry some disadvantages. These disadvantages include both cosmetic and functional problems, such as sensory loss in the grafted area, decreased

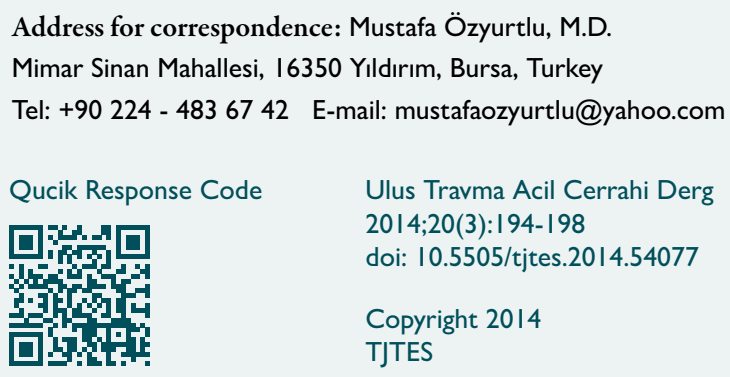

skin thickness, skin graft donor site problems, and possible complications that may be observed in the grafted area in the long-term as a result of unwanted adherences and the need for a secondary operation to fix these problems. ${ }^{[1-4]}$ The impossibility of primary closure in the early period following fasciotomy due to edema or wound tightness and possible long-term complications of skin grafting have led investigators to search for new methods with better outcomes both cosmetically and functionally.

There are various techniques in the literature describing the gradual primary closure of fasciotomy wounds by utilizing the elastic properties of the skin. In almost all of these techniques, with the regression of the edema after compartment syndrome, the margins of the wound are brought closer together gradually via a special device until the wound is completely closed. Some of the described methods are technically easy, whereas others are expensive and require special equipment.

In this study, we present a five-case pilot study demonstrating the feasibility of the V-Loc wound closure device (Covidien, Mansfield, MA), which is a barbed suture used routinely for 


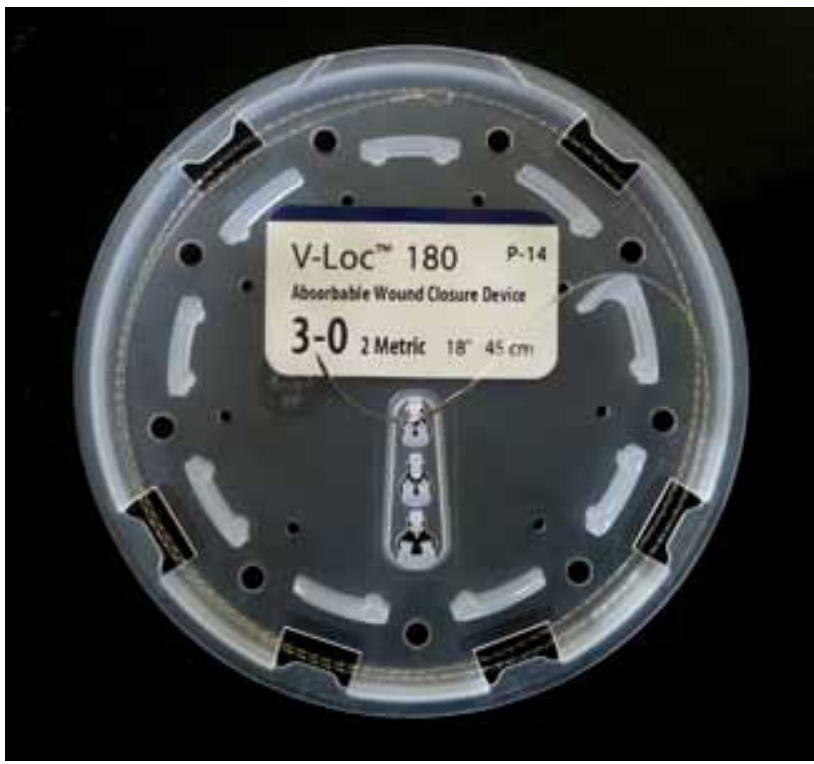

Figure 1. 3/0 cutting needle absorbable V-Loc wound closure device. It consists of unidirectional barbs and loop combination that are placed behind the suture.

surgical closures, as a gradual delayed closure technique for fasciotomy wounds.

\section{MATERIALS AND METHODS}

The V-Loc wound closure device was used as the barbed suture in this study. This device includes a combination of loop, unidirectional barbed suture and a needle, and is used for the closure of surgical incisions. This product has been designed in order to provide rapid closure and to shorten the operation time by eliminating the need for knot tying during tissue closure through its barbed design. Furthermore, it eliminates the need to knot for anchoring due to the loop design on the back end of the suture. In this study, two absorbable transparent $3 / 0$ V-Locs with cutting needles were used in each patient (Fig. I).

Between December 20II and May 2013, the V-Loc wound closure device was used in five different fasciotomy wounds, of varying size, occurring after compartment syndrome due to different causes. Demographic characteristics of the patients such as age, gender, affected extremity, and compart-

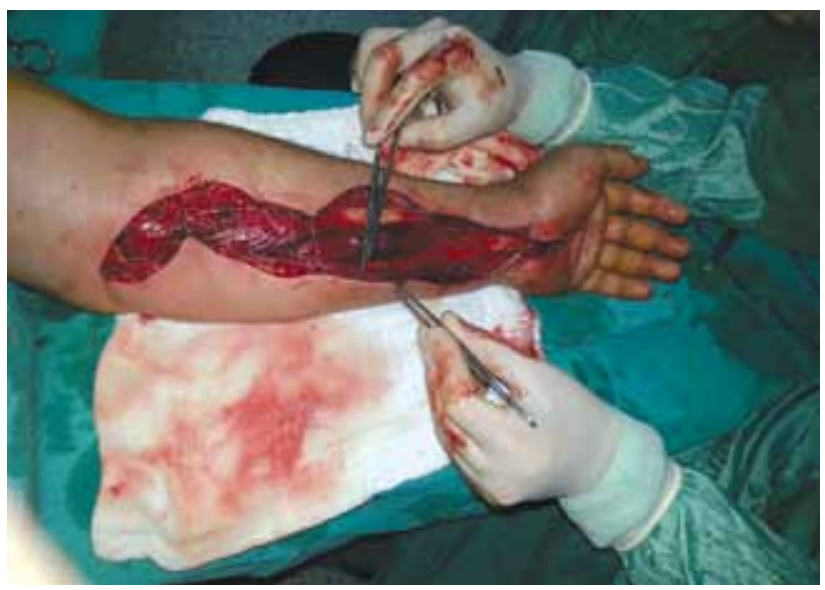

Figure 2. Perioperative view of the V-Loc wound closure device advancement in Case 4. After anchoring, the suture was advanced along the opposing wound edges in a horizontal mattress fashion.

ment syndrome etiology are shown in Table I. Placement of the barbed sutures was performed immediately after the fasciotomy in three cases and during the clinical follow-up in two cases. The placement of the device was performed under general anesthesia in all cases.

The first step of placement was the fixation of the barbed suture to the corner of the fasciotomy wound (anchoring). The needle of the suture was first passed through the dermis, and then through the loop at the back of the suture, and the fixation was completed. Subsequently, the suture was advanced along the opposing wound edges in a horizontal mattress fashion (Fig. 2). Again, all needles were passed through the dermis layer. Special attention was taken in the anchoring phase to ensure that healthy parts of the dermal sites were sutured. Passage of the suture through a subcutaneous plane rather than the dermis can lead to the rupture of these tissues by the suture since it is softer than the dermis. The suture was advanced, and the needle was finally inserted into the dermis and extracted from the skin. The needle was then passed through the rubber part of the injector piston. This maneuver was done to prevent the barbed part of the suture from catching on the rubber part and pulling back. After placement of the V-Loc on the edges of the wound, it was left loose, and an antibacterial closing dressing was applied to the fasciotomy wound. A bedside tightening procedure of the

Table I. Demographic characteristics of patients and causes of compartment syndrome

\begin{tabular}{lcccc}
\hline Patients & Age & Gender & Extremity with fasciotomy & Cause of the compartment syndrome \\
\hline Case I & 35 & Male & Upper extremity & Electrical burn injury \\
Case 2 & 37 & Male & Lower extremity & Blunt trauma \\
Case 3 & 30 & Female & Lower extremity & Gunshot trauma \\
Case 4 & 39 & Male & Upper extremity & Snake bite injury \\
Case 5 & 38 & Male & Upper extremity & Penetrating injury \\
\hline
\end{tabular}



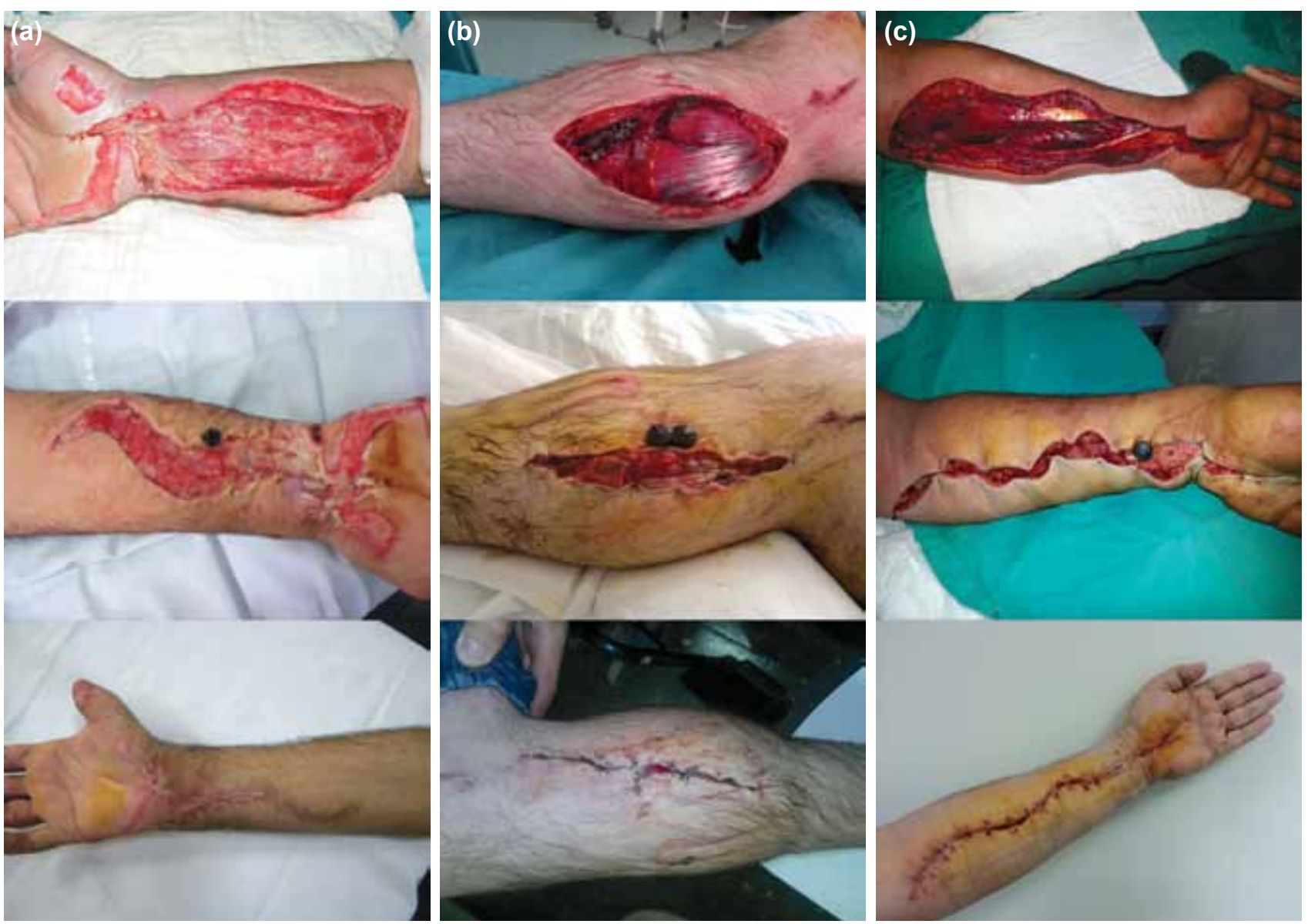

(a) View of Case 1. From top to bottom: Large open fasciotomy wound that occurred after high-voltage electrical injury (day 0 ) Approximated wound margins: note the tissue loss at the level of the wrist, which healed secondarily after debridement and dressings. Final result in the postoperative sixth month. (b) View of Case 2. From top to bottom: open fasciotomy wound at the lower extremity. Two $3 / 0$ cutting needle V-Loc wound closure devices were applied to the wound margins. Approximated wound edges after two tightenings (middle picture). Note the syringe pistol rubber that was placed to prevent the suture from pulling back (Case 2, day 4). Final result (day 6). (c) The gradual closure stages of Case 4. From top to bottom: large fasciotomy wound after snakebite injury, approximated wound margins on day 4 , and end result ( 15 days after opening fasciotomy).

suture was performed at 48-72-hour intervals for as far as the edema would allow. In order to minimize the pain during this tightening procedure, intramuscular analgesia was achieved by administering Pethidine (Aldolan, Liba, Istanbul, Turkey) to all the cases one-half hour before the tightening. The tightening procedure was continued until the edges met, and when a

Table 2. Size and location of fasciotomy wounds, widths of the wounds to be primarily closed, number of barbed sutures used for each case, total duration of wound closure with V-Loc, total duration of hospitalization, and complications

\begin{tabular}{|c|c|c|c|c|c|c|}
\hline Patient & $\begin{array}{l}\text { Wound size } \\
\text { and location } \\
(\mathrm{cm})\end{array}$ & $\begin{array}{l}\text { Width } \\
\text { of wound } \\
(\mathrm{cm})^{*}\end{array}$ & $\begin{array}{c}\text { Number of barbed } \\
\text { sutures used }\end{array}$ & $\begin{array}{l}\text { Time to primary } \\
\text { closure of the } \\
\text { wound }{ }^{* *} \text { (days) }\end{array}$ & $\begin{array}{c}\text { Total duration } \\
\text { of hospital } \\
\text { stay (days) }\end{array}$ & Complications \\
\hline Case I & $15 \times 9$ & 9 & 2 & 14 & 82 & $3 \times 2$ skin necrosis \\
\hline Case 2 & $15 \times 10$ & 10 & 2 & 10 & 10 & No \\
\hline Case 3 & $18 \times 8$ & 8 & 2 & 6 & 33 & No \\
\hline Case 4 & $21 \times 9$ & 9 & 2 & 7 & 7 & No \\
\hline Case 5 & $16 \times 8$ & 8 & 2 & 6 & 15 & No \\
\hline Mean & & $8.8 \mathrm{~cm}$ & & 8.6 days & & \\
\hline
\end{tabular}

*: The widest part of the wound planned to be brought together. **: Duration between the placement time of the barbed suture into the wound and the time of complete primary closure. 
total closure was achieved, skin staples were placed on the scar line to support the barbed sutures. Any excess barbed suture protruding from the skin was cut, and the remainder was left in since it was absorbable.

\section{RESULTS}

In one case, skin necrosis measuring $3 \times 2 \mathrm{~cm}$ was observed in the distal part of the fasciotomy line. The necrosis was removed following total closure and left for secondary healing (Fig. 3a). Complication-free total closure was obtained in all the remaining cases (Figs. 3b, c). Table 2 shows the wound sizes and locations, primary width of the wound to be closed, number of barbed sutures used, total duration required for closure in the V-Loc-applied wounds, and duration of hospital stay for each patient.

The mean duration between the day of suturing on the fasciotomy line and the day of complete primary closure was 8.6 days (8-14 days). The duration of hospital stay, on the other hand, differed according to the presence of additional trauma (7-82 days). The mean duration of perioperative $V$ Loc placement into the fasciotomy wound was approximately 3 minutes. The duration for bringing the wound edges closer in each session was approximately 2 minutes for each patient. No suture-related complication was observed in any of the patients (e.g., suture rupture, suture lock-up, or rupture of tissues by the suture).

\section{DISCUSSION}

Barbed suture V-Loc provided complete primary wound closure in the targeted regions of all patients. Only in Case I, who had fasciotomies in both upper and one lower extremity due to high-voltage electrical burn injury (Fig. 3), in whom barbed sutures were placed only on the upper right extremity, necrosis was observed in the distal part of the fasciotomy wound following complete closure. Debridement and dressings were performed on the necrotic area, and the wound healed secondarily within 22 days. The long hospitalization of this patient was due to the time needed for the reconstruction of the fasciotomy wounds and burn defects occurring in the remaining extremities. The duration of hospitalization for Case 3 was also long due to additional trauma (femur fracture).

There are various studies in the literature describing the gradual primary closure of fasciotomy wounds. ${ }^{[1-12]}$ Some of them included methods that were produced as a result of revising the equipment used in routine surgical practice, while others included techniques using specifically designed devices for dermotraction. The described methods were reported to yield successful outcomes.

With regards to the duration of gradual primary closure of fasciotomy wounds, our results were found to be similar to those of other studies. ${ }^{[1-4]}$ In the series by Taylor et al., Zor- rilla et al., Medina et al., and Govaert et al., mean delayed closure time was reported as 6.3 - 9.8 days. In our study, the mean duration of closure was found to be 8.6 days.

Our technique was most similar to the approximation with a prepositioned suture' technique previously described in the literature. ${ }^{[5,11]}$ In that technique, the monofilament sutures are placed on the edges of the wound, and tightening is performed at intervals in order to bring the edges of the wound together. The technical difference from our technique was that following each tightening procedure, the suture was knotted in order to prevent its pulling back. Rupture or lockups of the sutures may be observed during tightening. ${ }^{[4]}$ The presence of this possibility necessitates increased effort and time for each procedure. During the bringing together of the tissues by barbed sutures, the barbs are caught by tissues, thus preventing the sutures from pulling back. This non-pulling back property eliminates the need for fixation of the suture by knot- tying; therefore, the tightening procedures can be performed faster. A shorter tightening period will be less painful for the patient. There is no need for the suture to be removed after complete closure since it is absorbable, which is another advantage.

In Turkey, the cost of fasciotomy wound closure by STSG (split-thickness skin grafting) surgery is approximately 800 dollars. The cost of gradual wound closure by V-Loc, on the other hand, is approximately 80 dollars for each suture, and depends on the number of sutures used. Assuming that two sutures are used for a patient, gradual primary closure with barbed suture seems more economical than STSG. However, further comparative cost-effective studies with larger sample sizes should be carried out.

In conclusion, the gradual fasciotomy closure technique with barbed suture seems to be an easy, rapid and effective method. It may be applied to fasciotomy defects observed following compartment syndrome due to different causes. However, more attention should be paid in cases with dermal tissue damage, such as that due to burn injuries. Although our results demonstrate that this technique is reliable, further controlled studies are needed in order to demonstrate its efficacy.

\section{Conflict of interest: None declared.}

\section{REFERENCES}

1. Medina C, Spears J, Mitra A. The use of an innovative device for wound closure after upper extremity fasciotomy. Hand (N Y) 2008;3:146-51.

2. Taylor RC, Reitsma BJ, Sarazin S, Bell MG. Early results using a dynamic method for delayed primary closure of fasciotomy wounds. J Am Coll Surg 2003;197:872-8.

3. Zorrilla P, Marín A, Gómez LA, Salido JA. Shoelace technique for gradual closure of fasciotomy wounds. J Trauma 2005;59:1515-7.

4. Govaert GA, van Helden S. Ty-raps in trauma: a novel closing technique 
of extremity fasciotomy wounds. J Trauma 2010;69:972-5.

5. Chiverton N, Redden JF. A new technique for delayed primary closure of fasciotomy wounds. Injury 2000;31:21-4.

6. Harris I. Gradual closure of fasciotomy wounds using a vessel loop shoelace. Injury 1993;24:565-6.

7. Asgari MM, Spinelli HM. The vessel loop shoelace technique for closure of fasciotomy wounds. Ann Plast Surg 2000;44:225-9.

8. Walker T, Gruler M, Ziemer G, Bail DH. The use of a silicon sheet for gradual wound closure after fasciotomy. J Vasc Surg 2012;55:1826-8.
9. Caruso DM, King TJ, Tsujimura RB, Weiland DE, Schiller WR. Primary closure of fasciotomy incisions with a skin-stretching device in patients with burn and trauma. J Burn Care Rehabil 1997;18:125-32.

10. McKenney MG, Nir I, Fee T, Martin L, Lentz K. A simple device for closure of fasciotomy wounds. Am J Surg 1996;172:275-7.

11. Almekinders LC. Tips of the trade \#32. Gradual closure of fasciotomy wounds. Orthop Rev 1991;20:82, 84.

12. Harrah J, Gates R, Carl J, Harrah JD. A simpler, less expensive technique for delayed primary closure of fasciotomies. Am J Surg 2000;180:55-7.

\section{KLINIK ÇALIŞMA - ÖZET}

\section{Fasyotomi defektlerinin aşamalı primer kapatılmasında yeni ve basit bir yöntem Dr. Mustafa Özyurtlu, ${ }^{1}$ Dr. Süleyman Altınkaya, ${ }^{2}$ Dr. Yahya Baltu, ${ }^{2}$ Dr. Güzin Yeşim Özgenel ${ }^{2}$}

${ }^{1}$ Bursa Şevket Yılmaz Eğitim ve Araştırma Hastanesi, Plastik Cerrahi Kliniği, Bursa

2Uludağ Üniversitesi Tıp Fakültesi, Plastik ve Rekonstrüktif Cerrahi Anabilim Dalı, Bursa

AMAÇ: Bu çalışmanın amacı, kancalı (barbed) dikişler kullanılarak fasyotomi defektlerinin aşamalı olarak primer kapatılmasına olanak sağlayan ve literatürde daha önce tanımlanmayan, yeni, basit ve güvenli bir tekniğin gösterilmesidir.

GEREÇ VE YÖNTEM: Teknik beş farklı hastada, çeşitli etiyolojik nedenlere bağılı olarak gelişen kompartman sendromu sonrası açılan hem üst, hem de alt ekstremitelerdeki değişik boyutlardaki fasyotomi defektlerine uygulandı. Hastalarda yaklaştırılarak primer kapatılması planlanan ortalama defekt genişliği $8.8 \mathrm{~cm}$ idi. Fasyotomi açılmasını takiben, eriyebilir kancalı dikiş yara kenarlarındaki dermal dokudan subkutiküler kapatmaya benzer şekilde geçirildi ancak gevşek bırakıldı ve kapalı pansumana alındı.

BULGULAR: Klinik takipler sırasında doku ödemi ve yara kenarlarındaki gerginliğin azalmaya başlamasıyla birlikte, kancalı dikiş her 48-72 saatte bir yatakbaşı gerim yapıldı ve tüm olgularda aşamalı olarak ortalama 8.6 günde fasyotomi defektlerinin tamamı primer olarak kapatıldı. Yüksek gerilim elektrik yanığı nedeniyle fasyotomi açılan bir hastada defektin distal kısmında meydana gelen ve sekonder iyileşmeyle tedavi edilen nekroz dışında, tüm hastalarda komplikasyonsuz tam primer kapatım sağlandı.

TARTIŞMA: Sonuç olarak kancalı dikiş ile aşamalı fasyotomi kapatma yöntemi teknik olarak oldukça basit, hızlı ve etkili bir yöntem gibi görünmektedir. Çeşitli etiyolojilere bağlı olarak gelişen kompartman sendromu sonrası açılan fasyotomi defektlerine uygulanabilir.

Anahtar sözcükler: Aşamalı primer kapatım; fasyotomi yarası; kancalı dikişler; kompartman sendromu.

Ulus Travma Acil Cerrahi Derg 20 I4:20(3):194-198 doi: 10.5505/tjtes.20I4.54077 